\title{
Factors Influencing Motivation of the Tourism Actors in the Pulau Merah Banyuwangi, East Java, Indonesia
}

\author{
Kartina Ulva Setiawan¹, Iwan Nugroho², Rita Hanafie $2^{2 *}$ \\ 1Undergraduate Program, Faculty of Agriculture, Widyagama University of Malang,Malang, Indonesia \\ ${ }^{2}$ Department of Agribusiness, Faculty of Agriculture, Widyagama University of Malang, Malang, Indonesia
}

\begin{abstract}
The research aimed to identify the motivation of tourism actors and to analyze the factors influencing the motivation in Pulau Merah tourism area, Banyuwangi Regency. The object of the research is 61 business actors, consisting of homestay, souvenir shops, cafe, umbrella rental services, and travel operators. Respondents were selected using Stratified Random Sampling. Data were collected through interviews with questionnaires, and completed with secondary data from local villages. Data were analyzed with descriptive analysis and Multiple Linear Regression. The results showed that the motivation of business actors was in the high category with the score of $80.9 \%$. The actors' source of motivation to do business is derived from business benefits of $91.2 \%$, family or friends as high as $77.4 \%$, ideas and abilities as much as $83.3 \%$, and confidence to advance as much as $85.3 \%$. The result of Multiple Regression Analysis showed that motivation is significantly influenced by encouragement, action and satisfaction factors, each with a regression coefficient of $0.310,0.218$ and 0.265 , respectively. While the needs factor has no significant effect on motivation.
\end{abstract}

Keywords: Banyuwangi, motivation, Pulau Merah, social capital, tourism.

\section{INTRODUCTION}

Local governments start trying to develop and fix up their tourist destinations to attract either local or foreign tourists. Tourism sector has been given a priority in the local development which is expected to be able to give positive impacts on the improvement of the economy in the local area [1].

Banyuwangi is one of the most attractive tourism destination in East Java. Banyuwangi has abundance natural and cultural resources, in which many of them are rarely found in other place in the world. Banyuwangi has outstanding landscape, rich biodiversity and unique culture. These resources is principal component for the development of tourism industry [2].

Banyuwangi once obtained a rewards from United Nations World Tourism Organization (UNWTO) as The Winner of Re-inventing Government in Tourism for the category of Awards for Innovation in Public Policy Governance [3]. The contest that has been made since 2003 includes 153 countries and 350 members of the affiliation from all over the world. The activity was conducted in MadridSpain at January $20^{\text {th }}, 2016$.

One of the tourism destinations possessed by Banyuwangi Regency is marine tourist object,

\footnotetext{
${ }^{*}$ Correspondence address:

Rita Hanafie

Email : ritahanafi@widyagama.ac.id

Address: Widyagama University of Malang, Jl Borobudur 35 Malang 65128.
}

Pulau Merah in Pesanggrahan Sub-district. This island has started to be popular since 2013, when the government of Banyuwangi regency held an International Surfing Competi-tion followed by 20 countries.

The Pulau Merah tourism area is located in an area under the authority of Indonesia State owned Forest Enterprise (Perum Perhutani) in the residential environment of Pancer Hamlet, Banyuwangi. Therefore, the development of this destination is made under the cooperation of the government of Banyu-wangi Regency and the Perum Perhutani with the sustainable tourism vision $[4,5]$.

The development of Pulau Merah provides positive impacts on the socio-economic conditions of the community around this tourism object. The tourism actors gives various activities of tourist services such as food and beverage, home stay/accommodation, and other equipments. They gain experiences in tourism business, interact with visitors and also enjoy incomes. Moreover, they also recreate and innovate to give high-quality services to the visitors.

The tourism actors also have certain motivations in working on their business. The concept of motivation has been much expressed, it can be explained through need, encouragement, action and satisfaction [6]. The motivation come from internal and external factors. There is a psychological need to motivate oneself [7]. Motivation makes the tourism actors in Pulau 
Merah to be more creative to manage and develop their business.

Motivation emerges through push and pull factors. The higher the motivation, the higher the chance to attain the desired goals will be [8]. Incomes, opportunities, recognition or rewards, and security are sources of motivation [9]. Incomes become an important motivation of tourism actors [10]. Other sources of motivation are experiences, education and interactions with others [11]. Education becomes the source of one's motivation to work [12]. Interest in work also becomes the source of motivation besides wage and career path factors [13].

The actors of tourism want their business to progress and develop. They cooperate or compete with each other to give the best services and to develop their social capitals in the tourism services [14].Study on the motivation of tourism business actor in Pulau Merah has not much been revealed. By understanding the motivation, the tourism potentials could be explored and further developed to build the local tourism objects and improve regional economic development. The objective of this research were to identify motivation and analyze factors influencing motivation of tourism actors in Pulau Merah, Banyuwangi.

\section{MATERIALS AND METHOD \\ Data Collection}

This research was conducted in the tourism location in Pulau Merah, Banyuwangi Regency. Surveys and interviews were conducted on five types of local tourism SME, i.e. owners of home stay, souvenir shops, and providers of umbrella rental services, food stalls, and peddlers (Table 1).A stratified random sampling was employed where $30 \%$ of the population in the groups of business actors were chosen. Secondary data were obtained from the village demography data and tourism actors.

Table 1.Tourism Actors in Pulau Merah Banyuwangi

\begin{tabular}{lcc}
\hline Type of Business & $\begin{array}{c}\text { Population } \\
\text { (person) }\end{array}$ & $\begin{array}{c}\text { Sample } \\
\text { (person) }\end{array}$ \\
\hline Homestay & 40 & 12 \\
Souvenir shop & 4 & 4 \\
Umbrella rental services & 15 & 4 \\
Food stall owners & 126 & 35 \\
Peddlers & 20 & 6 \\
\hline Total & $\mathbf{2 0 5}$ & $\mathbf{6 1}$ \\
\hline
\end{tabular}

\section{Data Analysis}

A descriptive and regressive analysis was employed. Descriptive analysis of the data score [15] was made to identify motivation, needs, encouragement, action and satisfaction. The data were processed in the Likert Scale and were classified. Multiple regression analysis was made to study the factors influencing the motivation. The formula is as follows:

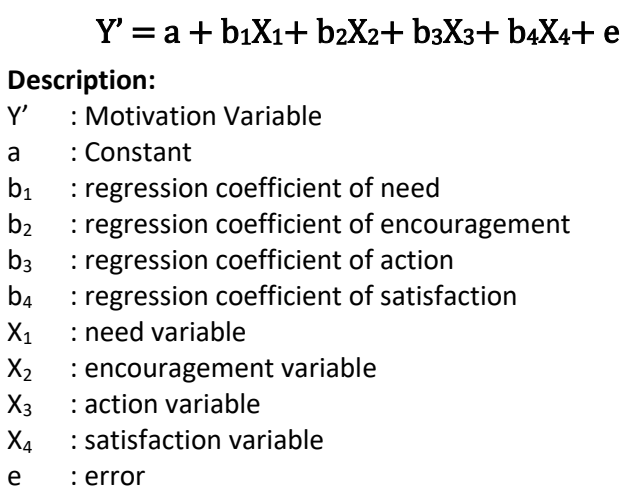

\section{RESULTS AND DISCUSSION \\ General Description of the Area}

Pulau Merah administratively located in Sumberagung Village, Pesanggrahan Sub-district, Banyuwangi Regency at coordinate of $114^{\circ} 26^{\prime}$ $114^{\circ} 35^{\prime} \mathrm{E}$ and $08^{\circ} 23^{\prime}-08^{\circ} 37^{\prime} \mathrm{S}$. The area of Pesanggrahan Sub-district is $\pm 80.36 \mathrm{~m}^{2}$, consisted of five villages, namely Sumbermulyo, Pesanggrahan, Sumberagung, Sarongan and Kandangan. The widest area is Sarongan Village with $47.04 \mathrm{~km}^{2}$ area, while the smallest one is Pesanggrahan Village with $2.63 \mathrm{~km}^{2}$ area (Fig. 1).

Sumberagung Village consists of four hamlets, namely Pancer, Rejoagung, Silirbaru, and Sungai Lembu, with the area of $6.99 \mathrm{~km}^{2}$, the altitude of $25 \mathrm{~m}$ asl. According to statistics in Pesanggrahan Sub-district in the year of 2016, the population number of Sumberagung Village is 13912 persons where the male population is 7038 , while the female 6874 persons [16]. The majority of the population (more than 60\%) live their life by cultivating crops and Palawija or secondary crops (Table 2). The service sector especially also develops to support the tourism in Pulau Merah.

Sumberagung Village has potential region for agricultural sector. Paddy is planted in the area of 672 ha with productivity of 7.76 ton per ha. While the productivity of corn and soybean is 6.08 and 1.33 ton per ha, respectively. Peanut is merely planted in a small amount (Table 3 ).

\section{Tourism in Pulau Merah}

Historically, this region is called Pulau Merah (or Red Island) since the content of the land and rock is reddish in color. In the morning, the fall of the sunshine on the rocks and land in the small island in the middle of the beach reflects reddish light from the coastal region. 


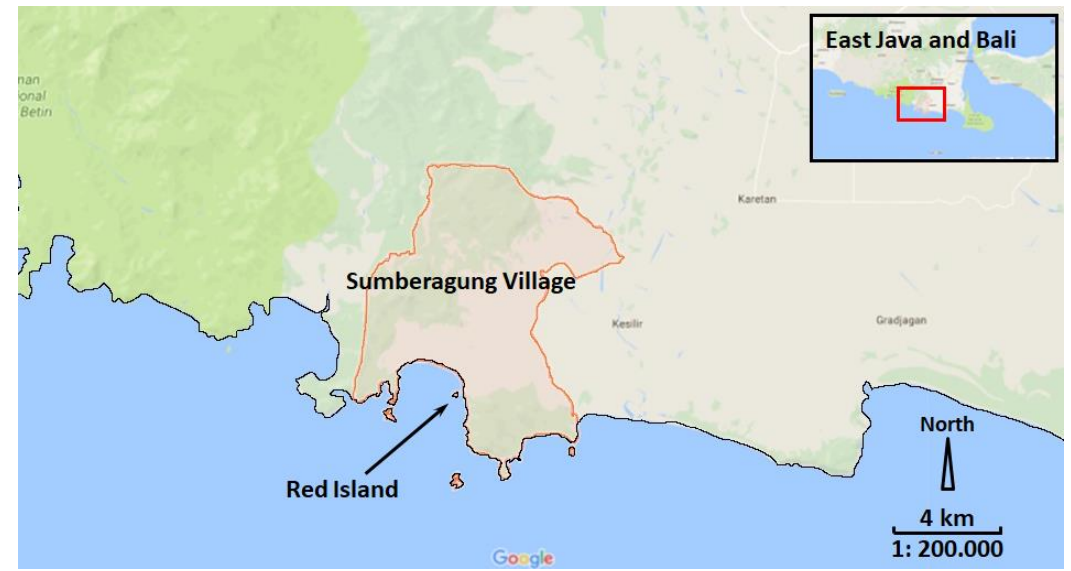

Figure 1. Map of Sumberagung Village (Source: googlemap, 2017)

Table 2. Labor Forcein Sumberagung Village [15]

\begin{tabular}{clr}
\hline No & \multicolumn{1}{c}{ Job } & $\begin{array}{r}\text { Number } \\
\text { (person) }\end{array}$ \\
\hline 1 & Crops and Palawija (secondary crops) & 5913 \\
2 & Horticulture & 89 \\
3 & Plantation & 570 \\
4 & Fishery & 712 \\
5 & Animal Husbandry & 17 \\
6 & Forestry and other agriculture & 11 \\
7 & Mining and digging & 173 \\
8 & Industry & 169 \\
9 & Construction & 56 \\
10 & Trading & 650 \\
11 & Hotels and Restaurants & 12 \\
12 & Transportation and warehousing & 90 \\
13 & Information and communication & 8 \\
14 & Finance and Insurance & 21 \\
15 & Education services & 103 \\
16 & Health services & 21 \\
17 & Social services & 261 \\
18 & Others & 84 \\
\hline & Total & $\mathbf{8 9 6 0}$ \\
\hline
\end{tabular}

Table 3. Commodity of Crops in Sumberagung Village [15]

\begin{tabular}{lrrc}
\hline $\begin{array}{l}\text { Crops } \\
\text { Commodity }\end{array}$ & $\begin{array}{c}\text { Area Harvest } \\
\text { (ha) }\end{array}$ & $\begin{array}{c}\text { Production } \\
\text { (ton) }\end{array}$ & $\begin{array}{c}\text { Productivity } \\
\text { (ton/ha) }\end{array}$ \\
\hline Rice & 672 & 5217 & 7.764 \\
Corn & 652 & 3962 & 6.076 \\
Soybean & 735 & 1334 & 1.815 \\
Peanuts & 6 & 8 & 1.345 \\
\hline Total & $\mathbf{2 , 0 6 5}$ & $\mathbf{1 0 , 5 2 1}$ & - \\
\hline
\end{tabular}

The hamlets in Pulau Merah was opened in 1967, pioneered by ex-army of the Republic of Indonesia, namely Kapi, Slamet, Mulyani, dan Lasmidi. They are ex-combatants who together with the people developed the area of Sumberagung Village which at that time was in the form of forest land up to the coastal region. Over time, the people's livelihood changed into fishery sector since the sea in this area is rich in fishes, lobsters and other sea biota to fulfill the need of the people in other area.
Then, Pulau Merah becomes a natural tourist object, therefore, a better management is needed. Pulau Merah is one of tourist destinations in the Tourism Development Area (TDA) III Sukamade. This island is located in the forest area managed by Perum Perhutani. At present, Pulau Merah tourism is managed on the cooperation agreement between Perhutani and Pulau Merah Forest Tourism Development in the area of the protected forest, Plot $70 \mathrm{~m}$ with the area of 3.46 ha of Forest Management Plan (FMP) and Plot $75 \mathrm{~m}$ with the area of 3.40 ha (FMP Silirbaru), within Coordinating Body for Forest Management (CBFM) Sukamade.

The location of Pulau Merah tourism object is $60 \mathrm{~km}$ to the south of Banyuwangi city that can be reached through Rogojampi, Srono, Jajag, Kesilir and Pesangrahan. It needs about 2.5 hours using cars to reach it. Tourists can use public transport services from the bus station in Banyuwangi. Then, after getting off the public transport, motorcycle (ojek) services can be used to come to the object.

The scenery in Pulau Merah is very beautiful. This beautiful scenery can be enjoyed when the sun sets where greenish orange sky among the hills is clearly seen. This situation is complemented with white and clean sands, natural mangrove vegetation, and strong waves from the Indian Ocean. Waves roll with $3 \mathrm{~m}$ long and $4 \mathrm{~m}$ high become a very interesting spot for surfers.

In 2013, an International Surfing Competition with participants from 20 countries was held in Pulau Merah. This competition has become an annual agenda in the Banyuwangi Festival calendar.

Some facilities in Pulau Merah are provided such as wide parking area, home stay in the coastal region, and some food stalls to relax to 
enjoy the sightseeing in the Pulau Merah coast. May to December are proper months to enjoy the beauty of the coast in the area [17].

Pulau Merah tourist object becomes popular among the people. The services provided improve in terms of number and varieties. A wide and cool parking place is shadowed with mangrove trees. New businesses are growing, covering umbrella rental services, food and beverages and also games.

\section{Motivation of Tourism Services Actors}

Description of the motivation of the actors in the tourism services in general was included into high category (score of 8.9), from the four questions on motivation (Table 4), namely benefits of services, seriousness in business, and the influence of friends and incomes.

Motivation from the perception of the benefits of tourism services showed the score of 91.2, a very high criteria. Most respondents answered very agree (56\%), and agree (44\%). The indicator of perception of the benefits gave the highest score than other indicators.

Dealing with indicator of seriousness in business, the answers were as follows: very agree $(57 \%)$, agree (39\%) and neutral (4\%). These answers are similar with those of the perception of motivation from the incomes, namely very agree (21\%), agree (69\%) and neutral (10\%). Meanwhile motivation coming from the influence (or imitation) from others showed the lowest score, even no respondent gave a very agree answer.

In general, the greatest motivation is from the benefits of the tourism services, followed by the seriousness in business, incomes, and the influence from friends, namely $91.2 \%, 90.8 \%$, $79.7 \%$ and $61.97 \%$, respectively. The first three indicators were considered as internal motivation, while the rest, external factors. From the number, internal factors seem to give stronger influences than external factors. Internal motivation influence the mechanism of one's psychological need to motivate his performance to attain his purpose of life [7].

\section{Factors Influencing Motivation}

The estimation of factors that influencing motivation are presented in Table 5. In general, the estimation resulted in a significant regression, at least one variable influenced motivation ( $t_{\text {count }} 2.793$ is higher than $t_{\text {table }} 1.672$ ), using the following equation:

$$
\mathrm{Y}=1.552-0.108 \mathrm{X}_{1}+0.310 \mathrm{X}_{2}+0.218 \mathrm{X}_{3}+0.265 \mathrm{X}_{4}
$$

Table 5 show that encouragement, action and satisfaction factors significantly and positively influenced motivation, each with the coefficient of $0.310,0.218$ and 0.265 , respectively. Meanwhile, the need variable did not give any significant influence on motivation, with the coefficient of -0.108 with the $p$-value of 0.283 .

A question dealing with need consisted of three indicators namely, need, incomes, and socialization. The three indicators cannot significantly contribute to motivation, although the context of the three is relatively known in terms of motivation. This phenomenon shows that the might some bias in perception among respondents to the question.

Encouragement factor $\left(\mathbf{X}_{\mathbf{2}}\right)$ showed a significant and positive influence to motivation of tourism actors. Indicators dealing with encouragement cover the influence from family/ friends, consumers, influence from fellow tourism actors and appreciation from the public. The indicators show external factors.

From the results of the score calculation, it is known that the strongest indicator is presented by the encouragement from the family or friends namely $77.38 \%$, followed by appreciation from

Table 4. Motivation of Pulau Merah Tourism Actors

\begin{tabular}{|c|c|c|c|c|c|c|c|c|c|c|}
\hline \multirow{2}{*}{ No } & \multirow{2}{*}{ Indicator of Motivation } & \multicolumn{5}{|c|}{ Frequency of Score } & \multirow{2}{*}{$\begin{array}{l}\text { Actual } \\
\text { Score }\end{array}$} & \multirow{2}{*}{$\begin{array}{l}\text { Ideal } \\
\text { Score }\end{array}$} & \multirow{2}{*}{ Percent } & \multirow{2}{*}{ Criteria } \\
\hline & & VA & A & $\mathbf{N}$ & DA & VDA & & & & \\
\hline 1 & Giving benefits to life. & 34 & 27 & 0 & 0 & 0 & 278 & 305 & 91.18 & Very High \\
\hline 2 & Seriousness in business & 35 & 24 & 2 & 0 & 0 & 277 & 305 & 90.82 & Very High \\
\hline 3 & $\begin{array}{l}\text { Following and imitating others in } \\
\text { developing business }\end{array}$ & 0 & 19 & 33 & 5 & 4 & 189 & 305 & 61.97 & Moderate \\
\hline \multirow[t]{2}{*}{4} & Incomes from Tourism Services & 13 & 42 & 2 & 0 & 4 & 243 & 305 & 79.67 & High \\
\hline & Average & 20.5 & 28 & 9,25 & 1.25 & 2 & 246.75 & 305 & 80.91 & High \\
\hline
\end{tabular}

Sources: Research Result

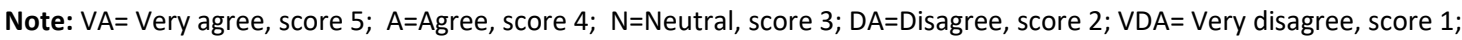

a. Actual score is obtained from the addition of the frequency score multiplied with answer score

b. Ideal score is obtained from the number of respondents $(=61)$ multiplied with answer score of very disagree $(=5)$

c. Percent is obtained from the actual score divided by the ideal score

d. Criteria of the scores of respondents' answers (i) $20.00-36.00$ Not High, (ii) $36.01-52.00$ Less High, (iii) $52.01-$ 68.00 Moderate, (iv) 68.01 - 84.00 High and (v) 84.01 - 100.00 Very High 
Motivation of the Tourism Actors in the Pulau Merah, Banyuwangi, East Java

(Setiawan, et al.)

Table 5. Estimation of Motivation

\begin{tabular}{clcc}
\hline No & Estimator & coefficient & p-value \\
\hline 1 & Need $\left(\mathrm{X}_{1}\right)$ & -0.108 & 0.283 \\
2 & Encouragement $\left(\mathrm{X}_{2}\right)$ & 0.310 & 0.016 \\
3 & Action $\left(\mathrm{X}_{3}\right)$ & 0.218 & 0.002 \\
4 & Satisfaction $\left(\mathrm{X}_{4}\right)$ & 0.265 & 0.006
\end{tabular}

Note: $p$-value $=0.05$

the public, $73.77 \%$, then the influence of consumers and help from fellow tourism actors, $67.54 \%$ (Table 6). Encouragement from others gave two motivations, namely primary motive or motive which is not learned and secondary motive or motive which is learned. The motives are built from experiences and interaction from other people [11].

Action Factor $\left(\mathbf{X}_{3}\right)$ showed a significant and positive influence to motivation. The strongest indicator in action is shown by the ability of idea of $83.28 \%$, followed by the indicator of imitating or following other tourism actors of $73.44 \%$, and the guidance and training by the manager of Pulau Merah tourism of $71.48 \%$ (Table 6 ).

Action variable is real action made by someone to attain a certain goal. Tourism actors shows real performance as part to motivate their lives. This ability to act is also influenced by experiences, education and also interaction with others [11]. Education is one of a worker's motivations in developing his role in organization [10].

Satisfaction $\left(\mathbf{X}_{4}\right)$ showed a positive and significant influence. Satisfaction is the feeling of happiness or pleasing in an environment since all needs are adequately met. Satisfaction in this present research is shown through indicators of income, facility, security, additional know-ledge, and better and management (Table 6).This motivation is also in line with previous study [9] on the Palace Tourism object, in Siak Regency, Riau province.

The management of Pulau Merah tourism has been growing and getting crowded during the last five year. The organization of the management is able to formulate job descriptions and authorities in order to give satisfactory services. Its structure is developing, following the functions of services. Facilities and tourist accommodation improve such as souvenirs, water sport or other facilities. The management also has paid attention to the security aspect of the visitors.

Better management also gave effects on the increase of the visitors. The tourism actors were intensively interacted with the visitors through better services, and giving additional experiences a knowledge. These positive things can give impacts on the improvement of the tourism actors' incomes (money follow function) [10].

\begin{tabular}{llcc}
\multicolumn{4}{c}{ Table 6. Indicator of Motivation Factor } \\
\hline No & Indicator & $\%$ & Criteria \\
\hline & Need & & \\
1 & Meet the need & 85.90 & Very High \\
2 & Improving income & 88.5 & Very \\
3 & Socialization & 79.02 & High \\
\hline & Average & 84.59 & Very High \\
\hline & Encouragement & & \\
1 & Family or friend & 77.38 & High \\
2 & Number of consumers & 70.82 & High \\
3 & Help from fellow traders & 67.54 & Moderate \\
4 & Appreciation of the public & 73.77 & High \\
\hline & Average & 72.38 & High \\
\hline & Action & & \\
1 & Idea and ability & 83.28 & High \\
2 & Imitating or following friends & 73.44 & High \\
3 & Guidance and training & 71.48 & High \\
\hline & Average & 76.07 & High \\
\hline & Satisfaction & & \\
\hline 1 & Income obtained & 73.77 & High \\
2 & Facilities provided & 64.26 & Moderate \\
3 & Assurance of security & 74.10 & High \\
4 & Additional knowledge & 79.34 & High \\
5 & Better management & 85.25 & Very High \\
\hline & Average & 75.34 & High \\
\hline & & &
\end{tabular}

\section{Implication on Social Capital}

The results showed that factors influencing motivation can be implemented in the development of tourism management. Indicators in the encouragement, action and satisfaction factors should be developed to produce social capital.

Encouragement indicators, such as help from the fellow tourism actors or appreciation from the public and action indicators, such as guidance and training, are external factors that should be coordinated and developed. It should be reinforced by internal factors in the action indicators, for instance, ideas or creativities, or additional knowledge obtained by tourism actors (satisfaction indicator). The combination between external and internal factors should be in line with its improvement and development.

Tourism actors should be empowered, thus they would keep developing and growing. They need to be assisted by NGOs, academicians or the local government in terms of a well-planned sustainable conservation and tourism services programs [3,5]. Pulau Merah tourism object needs the touch of the education, innovation, promotion, cooperation and research [6]. These efforts need the management of tourism services and also the construction of social capital in Pulau Merah [5,14], covering:(i) development of 
trust between the actors and other stakeholders; (ii) improvement of real relation and cooperation; (iii) development of mechanism of institutional (organizational) rules to anticipate the increase of tourism services; and (iv) development of participation so that all stakeholders actively give their roles.

Social capital reinforcement is increasingly more relevant since Pulau Merah tourism encounter two things that threaten the environmental conservation. First, the increasing number of visitors potentially create mass tourism. Second, pollution potentially come from gold mining since the location of the mining is near the tourism location.

Implications of the improvement on motivation among the tourism services actors that need support, are: (i) better management of tourism organization; (ii) guidance management, especially technology from the NGOs or government; (iii) cooperation among the tourism actors to improve knowledge and skills; and (iv) developing of creativities of ideas or innovations of tourism services.

\section{CONCLUSION}

Actors' motivation in Pulau Merah tourism was in high category (score 80.0). The greatest motivation gained from the indicator of benefits from tourism services, followed by seriousness in business, income, and influence from friends, each with the score of 91.2, 90.8, 79.7 and 61.97 percent, respectively. Encouragement, action and satisfaction have significant positive effects on motivation, each with the coefficient of 0.310 , 0.218 and 0.265 , respectively. Meanwhile, the need variable did not have any significant effect on motivation.

\section{REFERENCES}

[1] Nugroho, I. 2010. Pengembangan ekowisata dalam pembangunan daerah. Jurnal Pembangunan Daerah 2010(1), 65-76.

[2] Hakim, L. 2008. Planning for nature-based tourism in East Java: recent status of biodiversity, conservation, and its implication for sustainable tourism. ASEAN Journal on Hospitality and Tourism 7(2), 155167.

[3] National Geographic. 2016. Indonesia raih juara dunia $12^{\text {th }}$ UNWTO Award. Available at: http://nationalgeographic.co.id/berita/2016 /01/indonesia-raih-juara-dunia-12th-unwtoaward.

[4] Nugroho, I. 2007. Ekowisata: sektor riil pendukung pembangunan berkelanjutan.
Majalah Perencanaan Pembangunan 12(2), 44-57.

[5] Nugroho, I. andP. D. Negara. 2015. Pengembangan desa melalui ekowisata. Era Adicitra Intermedia Publisher.Solo.

[6] Shanks, N. H. 2007. Management and motivation. In: Buchbinder, S.B. and N. H. Shanks (Eds). Introduction to Health Care Management. Jones \&Bartlett Publishers, Masachusetts. Sudbury.

[7] Dobre, O.I. 2013. Employee motivation and organizational performance. Review of Applied Socio-Economic Research 5(1), 5360.

[8] Pitana, G. andP. Gayatri. 2005. Sosiologi pariwisata. Andi Offset Publisher.Yogyakarta.

[9] Buiman. 2015. Motivasi pedagang berjualan di lokasi obyek wisata Istana Siak, Kabupaten Siak. Jurnal Online Mahasiswa Bidang IImu Sosial dan Ilmu Politik2(2), 1-13.

[10] Avriatama, B. 2016.Dampak pengembang-an wisata terhadap pendapatan rumah tangga pelaku usaha disekitar Pulau Merah. Thesis. Department of Economy Education, University of Jember. Jember.

[11] Notoatmodjo, S. 2007. Promosi kesehatan: teori dan ilmu perilaku. Rhineka Cipta Publisher. Jakarta.

[12] Živković, Ž.,I.Mihajlović and S. Prvulović. 2009. Developing motivation model as a strategy for HRM in small enterprises under transitional economy. Serbian Journal of Management 4(1), 1-27.

[13] Sherif, M. Z., M. U. Nimran and A. Prasetya. 2014. The role of motivation in human resources management: the importance of motivation factors among future business professionals in Libya. Journal of Business and Management 16(8), 27-36.

[14] Baksh, R., Soemarno, L. Hakim and I. Nugroho. 2013. Social capital in the development of ecotourism: a case study in Tambaksari Village Pasuruan Regency, East Java Province, Indonesia. Journal of Basic and Applied Scientific Research 3(3), 1-7.

[15] Narimawati, U. 2007. Riset manajemen sumber daya manusia. Agung Media Publisher. Jakarta.

[16] Statistic Center of Banyuwangi. 2016. Pesanggaran dalam Angka 2016. Statistic Center of Banyuwangi. Banyuwangi.

[17] Banyuwangi Tourism. 2017. Available at: http://banyuwangitourism.com/List_event. 